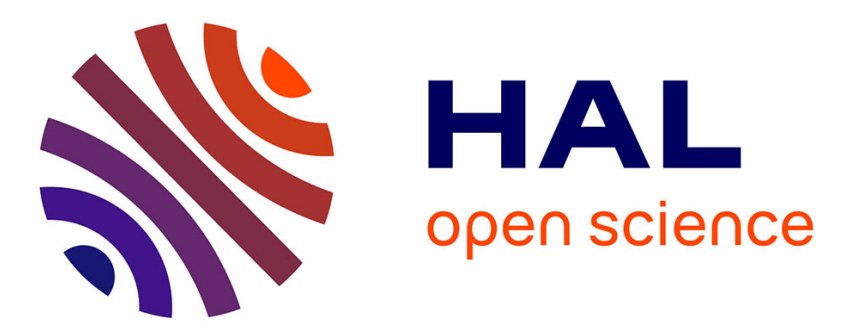

\title{
Becoming a Muslim in the Age of Social Networking Sites: Facebook as a Space Shared by the French Converts to Islam
}

\author{
Mohamed Sakho Jimbira
}

\section{- To cite this version:}

Mohamed Sakho Jimbira. Becoming a Muslim in the Age of Social Networking Sites: Facebook as a Space Shared by the French Converts to Islam. Journal of Islamic Studies and Culture, 2017, 5 (2), pp.40-46. 10.15640/jisc.v5n2a5 . hal-02975242

\section{HAL Id: hal-02975242 \\ https://hal.univ-lorraine.fr/hal-02975242}

Submitted on 22 Oct 2020

HAL is a multi-disciplinary open access archive for the deposit and dissemination of scientific research documents, whether they are published or not. The documents may come from teaching and research institutions in France or abroad, or from public or private research centers.
L'archive ouverte pluridisciplinaire HAL, est destinée au dépôt et à la diffusion de documents scientifiques de niveau recherche, publiés ou non, émanant des établissements d'enseignement et de recherche français ou étrangers, des laboratoires publics ou privés. 
Journal of Islamic Studies and Culture

December 2017, Vol. 5, No. 2, pp. 40-46

ISSN: 2333-5904 (Print), 2333-5912 (Online)

Copyright (C) The Author(s). All Rights Reserved.

Published by American Research Institute for Policy Development

DOI: $10.15640 /$ jisc.v5n2a5

URL: https://doi.org/10.15640/jisc.v5n2a5

\title{
Becoming a Muslim in the Age of Social Networking Sites: Facebook as a Space Shared by the French Converts to Islam
}

\author{
Mohamed Sakho Jimbira ${ }^{1}$
}

\section{Introduction}

Conversions to Islam in France have been at the heart of religious and political news since the 1990s. Recently, the debates around this phenomenon call to the imagination of an "Islamization" of France with an increase in the number of converts since the attacks of January $2015^{2}$. Moreover, some journalists do not hesitate to argue that converts to Islam have been involved in activities related to terrorism ${ }^{3}$. My purpose is not, of course, to explain why many French people convert to Islam, several works have already dealt with this (Riva 2015; Brun 2014; Mossière 2013; Puzenat 2010; Allievi 1998). Nevertheless, despite this abundant literature, it must be emphasized that reflections on the articulation between conversion to Islam and the use of TNIC (digital information and communication technologies) remain marginal in the academic literature.

In this chapter, I shall, on the one hand, consider and question the logics underlying three accounts of conversions and, on the other hand, analyse the way in which certain French converts, suffering from isolation, are trying to unite on Facebook. The methodological approach adopted, which I do not develop in detail ${ }^{4}$, is qualitative, based on open-ended, ethnographic observations conducted on Facebook for several months. The three women who are the subject of this chapter are part of the data collected for my doctoral research ${ }^{5}$ on the relationship between Islam and social networks. The testimonies collected from Amel and Anastasia deal with their biographical histories prior to conversion and their journey towards Islam. As for Charlene, as we shall see below, her discourse will mainly revolve around her use of Facebook.

All three are French nationals and reside in different localities of France. They share a relatively high level of academic qualifications because they have studied in higher education institutions. They are part of Facebook groups dedicated to new French converts to Islam. These groups bring together thousands of converts and can be considered as spaces of socialization. For reasons of confidentiality, and in accordance with their wishes, the names of the interviewees were modified. My reflection will then be articulated into two focus points: I shall first consider the said three accounts and the logics that underlie them, and then I shall ask how Facebook converts try to constitute a Facebook community.

\section{Presentation of three conversion routes: The case of Anastasia, Amel and Charlene}

\footnotetext{
${ }^{1}$ Doctor of Information and Communication Sciences, Faculty of Information and Communication Sciences, University of Lorraine (Metz/France). Email:mouhamedsakho@yahoo.fr

${ }^{2}$ Werefer the reader to the RTL article: «De plus en plus de convertis à l'islam depuis les attentats ». Access: http://www.rtl.fr/actu/societe-faits-divers/de-plus-en-plus-de-convertis-a-l-islam-depuis-les-attentats-7776542923.

${ }^{3}$ Werefer the reader to the article in L'Express: «Pourquoi y a-t-il tant de convertis parmi les djihadistes français de l'Etat islamique ? ». http://www.lexpress.fr/actualite/societe/pourquoi-y-a-t-il-tant-de-convertis-parmi-les-djihadistes-francais-de-l-etatislamique_1624282.html

${ }^{4}$ For more details on the methodological and ethical issues inherent in my Facebook research, see (Sakho Jimbira 2015; 2016).

${ }^{5}$ As part of my doctoral research, 31 semi-structured interviews, offline and on-line via Facebook and telephone, were conducted in two phases with Muslim users who are present on Facebook for religious purposes.
} 
From the outset, let us remember that the conversion to Islam is the adoption of beliefs, dogmas and Muslim rites. Even though the notion of conversion as such is not mentioned precisely in the Koran and the term does not exist in the Arabic language, the process of conversion is relatively simple: it is enough to recite the Shahada which means the profession of faith. Islam being not structured around a clergy, nor around a specific initiation ritual space, the act of conversion can theoretically be done in a private environment.

Our three witnesses are of interest, as they illustrate the individual paths of conversion and identity and religious logic that emerge from it. Respondents are part of Facebook groups "Converted from France and sympathizers", and "French grouping and European converts to Islam", created in 2014. Both Facebook groups express three main objectives:

(1) Allow converted people to get in touch and have easy contacts with their cities as common denominator; (2) To gather the testimonies of conversion; (3) Allow people to find a listening ear, a place to ask questions or share problems.

\section{Anastasia}

Born in 1984, Anastasia is a young French woman living in Paris who converted to Islam at the age of 29. She describes her route:

"I stopped religious practice for quite some years. The Catholic religion in which I grew up seemed incomplete, and even strange sometimes. So, I stopped believing in God at a very young age. Which of course led to bad behaviour, but Allah is merciful. At 19, I met a man who was very nice, but did not believe in God. I lived in cohabitation and sin for 11 years. May Allah forgive me! One summer evening, August 21, 2013, I met the person who changed my life. We talked via the internet and by written messages. This man, may Allah be merciful to him, told me, knowing virtually nothing of Islam, about his religion. Our discussions were always held in courtesy, and when he talked to me about Islam, I felt the love, respect, strength emanating from this religion and I wanted to know more. I felt this power overwhelming me, that's it, Allah had called me to guide me towards him. Subsequently, I did research on the internet and read testimonials of converts to learn about Islam. I filled myself with truth and love, but the turning point was when I heard for the first time the call to prayer, I was hovering, tears streaming from my eyes, I even think my heart stopped beating to relive again. No doubt, it is with Allah that I want to be, I do not want to live in sin anymore. I left my companion who did not share any longer my decision to convert to Islam. I did not want to live in sin. May Allah guide him in the right path! My parents who are Catholics knew my conversion only six months later, as I was afraid of their reaction. Today I am happy and proud to be Muslim. I hope to get married one day Inch Allah with a godly man who respects the religious requirements and with whom I could perfect my knowledge. [...] Thanks to Facebook, I got to know and meet other converts, and I try to do my best to be useful for the community and help new converts to Islam". (Interview held in September 2014)

\section{Amel}

Aged 28, Amel lives in Paris and works as a sales assistant. Converted two years now, she says she always believed in God and describes her route as follows:

"I was raised by my grandparents, who are Portuguese and very devout Catholics. So, I received a Catholic religious education. From an early age on, I put the finger on things that seemed inconsistent or even bizarre. I raised a lot of contradictions in the Bible and in Christian religious practices. In the Bible, the ban on eating pork is mentioned, but despite that ban Catholics eat pork. Other issues also puzzled me. For example, why Jesus was painted like a Frenchman when he was supposed to come from the East? In short, to a lot of questions I did not have the answer. Still, I had faith in God, but soon I realized that this religion was not mine. In high school, I discovered with my French teacher, an extract from the Quran, I who already liked words, I was sensitive to the beauty of this text. All this was far from the image which the media served us about Islam and Muslims.

${ }^{6}$ The "Shahada" is summarized in two points: the first part is to testify "that there is no God except Allah"; the second part is to testify "that Muhammad is his servant and messenger". 
I must say that when I was younger, I always had a great affinity with my Muslim friends, we got along great. Then, the more I asked about Islam, the more I discovered a world of information which instead of contradicting itself (as in the Bible) was about to become even more concrete and credible. After studying the Quran and doing some research, I realized that it was infallible and that it contained no contradiction. I did not convert right away, but I had no doubt about the veracity of this book. May Allah forgive me for not having done so at that time, but I was young and too dependent on my family (I was afraid they would reject me.). It is only after several months of reflection that I decided to convert to Islam. Besides, I felt very alone after my conversion, but now I feel much better. Over the last three years since I converted, my faith grew. I'm also part of a group of converts on Facebook, and again, I try to put things online that may be helpful to sisters. I wish I could share the little knowledge that I have and especially have practical sense of belonging to our community. Through Facebook, I can talk to other girls converted to Islam and feel less alone, because conversion is often synonymous with loneliness and in France many converts to Islam will experience a rejection of those around them".

(Interview held in September 2014)

\section{Charlene}

Born in 1987, Charlene lives in Bar-le-Duc, a French commune in the Department of Meuse. She converted to Islam at the age of 19. She is very active on Facebook in groups supporting converts. In this regard, she explains:

"Early 2014, starting from my personal experience and not knowing where to start, what books, what authors and scholars to turn to, I tried to solve these problems. So, I started listening, cross-checking accounts, and listing the main problems, obstacles to learning, needs and ideas. Then I imagined how we might address them and meet the needs of new converts. [...] I got the idea one morning to open the Facebook social network of a 'group' (sort of forum) for converts in France. Without knowing where it would lead me, we had in the very early days, a lot of success. I invited my converted friends and acquaintances, and worked very hard especially in terms of exchange of documents, personal work that people had made, testimony and rich dialogue. The group achieved in a few months Praise be to Allah - the status of a veritable 'institution' for converts to join. I think it is important from a religious point of view to connect converted people. To help the community, I regularly publish religious content with pedagogical purposes, such as extracts from the Koran, hadith, sermon videos. My main goal was to create a database available on Facebook, including all the basics of this religion, to help those who come to be converted. Also, this is to link people converted to Islam in France to help each other either locally or virtually and to try to answer the questions converts frequently ask". (Interview held in October 2014)

As the testimonies of Anastasia and Amel show, the narrative raises the problematic of retrospection, the search for the root causes of a journey. The narrative of the religious experience of 'conversion' thus finds itself at the crossroads of the exercise of autobiographical testimony, and in this sense, can be qualified as a kind of spiritual autobiography. On the latter, SrđanSremac (2010: 19) states: "Likewise conversion stories can be understood as intelligible narratives or life stories, a special form of autobiographical narrative ». As far as conversion is concerned, it is often viewed from a psychological point of view as a renewal which implies a profound transformation of the self in the sense of Ulrike Popp-Baier (2002). In the context of Islam, the act of conversion translates into a change of social identity insofar as it enshrines the convert's entry into the Ummah (the Muslim community). Adherence to Islam is linked to a social process characterized by identity, social interaction and daily religious practices. Conversion would therefore transform the deep identity of the convert. It is precisely in this context that Anastasia and Amel consider their conversion as a kind of realization and transformation of self. The reading of their narratives highlights the failure of personal achievement in Catholicism. Moreover, according to Lewis (1993), the choice to convert sometimes occurs due to situations of personal disappointment and distress. Indeed, frustrated by a Christian tradition that has not been able to satisfy their 'spiritual hunger', they consider their journey towards Islam as the conclusion of a troubled past: the past is negatively connoted while the future holds many promises. Their individual conversion process is the result of a spiritual quest and personal well-being. They are very concerned with a search for a certain form of piety, because they now place the question of spirituality and purification at the heart of their daily lives. Islam brings them to perpetual introspection in a spiritual fulfilment process. In this sense, adherence to Islam implies a spiritual work up on oneself and opens a form of religiosity experienced as the hermeneutics of the self in the sense of Michel Foucault (Foucault, 2001). 
Furthermore, we want to underline that, like autobiographical narratives, the narrative of conversion has as its theme the personal identity. In this perspective, Anna Mansson McGinty (2009: 6) clarifies:

"Conversion triggers profound questions to the self; it heightens the awareness and prompts reflections of who one is, who one was, and where one is heading. It captures both popular and scholarly interest since it raises critical problems regarding human being reflections on the meaning of life and their relation to a metaphysical sphere".

The narrative fulfils an essential function because it makes it possible to structure the events and bring them the necessary coherence. Thus, through the mediation of the narrative, Amel and Anastasia try to reconstruct their identity, for as Paul Ricœur (1990) shows, "narrative identity" is constructed from the self-narrative that an individual formulates. In fact, the narrative of the self has the function of giving coherence to its history, of presenting itself as the same person, different from another, despite "the effect of the rupture of unpredictable events" (Ricœur, 1990: 175) that threaten this coherence. Individuals build themselves through a narrative project in which they elaborate a story by articulating various disparate elements of life experiences, events, actions and intentions, around an intrigue. To this end the self-narrative supposes to be able to take distance with regard to one's past and what one has been. It is therefore necessary to be different from oneself, for it is on this condition that convert manage to observe the changes which have marked their narrative existence. In this sense, for Anastasia and Amel, the narration of their own experience plays an essential role in their approach to building identity.

Regarding Charlene, unlike Anastasia and Amel, her speech does not focus on the path towards Islam, but rather on the reasons that led her to create on Facebook a group dedicated to French converted to Islam. Indeed, on the pretext of the difficulties encountered by many converts, Charlene has set up this meeting space and support to provide solutions to the needs of converts who often suffer from isolation. Within this space, several resources are offered: initiation courses to religious practice that take several formats (Word texts, Pdf, audio content, video). The main objective here is to help the convert to master religion both theoretically and practically. In addition, other forms of support are offered: emotional, informational and material. Emotional support most often translates into comfort, friendship, encouragement. It aims to testify to the other of a positive, affective bond (sympathy, friendship, respect, listening, etc.). Naturally, it is possible to go beyond this minimal support. As for informational support, it concerns the exchange of information likely to meet the needs of the convert. And finally, the material support aims to solve a problem by the contribution of various resources (donations, financial aid...) outside of Facebook.

In addition, it is emphasized that Charlene's engagement on Facebook is not trivial as it is motivated by her religious beliefs. The links between faith and commitment are contiguous, in this sense, religious faith gives meaning to the commitment. De facto, it is not only to provide some assistance but more fundamentally to fulfil a duty of moral and religious solidarity. Indeed, it is mentioned in many verses of the Koran that Muslims are one family; they are siblings, they must help each other, refraining from division and dispersal:

"And hold firmly to the rope of Allah all together and do not become divided. And remember the favour of Allah upon you -- when you were enemies and He brought your hearts together and you became, by His favour, brothers. And you were on the edge of a pit of the Fire, and He saved you from it. Thus, does Allah make clear to you His verses that you may be guided". (Surah 3: verse 103) “The believers are but brothers, so make settlement between your brothers. And fear Allah that you may receive mercy". (Surah 49: verse 10)

"Call them by [the names of] their fathers; it is more just in the sight of Allah. But if you do not know their fathers - then they are [still] your brothers in religion and those entrusted to you. And there is no blame upon you for that in which you have erred but [only for] what your hearts intended. And ever is Allah Forgiving and Merciful". (Surah 33: verse 5).

\section{Online regrouping: a response to the solitude of converts}

The social network Facebook allows converts residing in different localities of France to establish new ways of being together by forming an online community. In this context, like Amel, Anastasia and Charlene, many converts cultivate social relations with their co-religionists who rely on the sharing of common sensibilities. It must be said that conversion to Islam creates a social bond insofar as it generally involves belonging to a community of faith (the Ummah). In this perspective, Facebook gives consistency to the links established online, because the fact of recognizing in the other the belonging to the same community of oneself will significantly influence the relationship woven online. 
Thus, without weakening the social bond between converts, the new solidarity based on the sharing of common sensitivities is manifested, relations of friendship are forged between converts and support initiatives are developed. Thus, the reproduction of social relations on Facebook is a strategy adopted by the converts especially in the French context to overcome the difficulties they encounter in everyday life. The French republican model is characterized by the principle of secularism which confines religious beliefs in the private sphere, which is why converts tend to play discretion as to the public exposure of their new beliefs in the public space. In addition, online ethnographic observation shows that many converts who are rejected by their families are signing up to Facebook to break their isolation and regain social ties, as suggested by the screenshots ${ }^{7}$ in this chapter. Hence, it is important to point out that, following their conversion, Anastasia, Amel and Charlene lived for a while in anonymity, insofar as conversion to Islam is often perceived by the family circle as a denial of the original religious culture.

Image 1 : Excerptcaptured on June 09, 2014 (groupe Regroupement des français et européens convertis à l'islam)

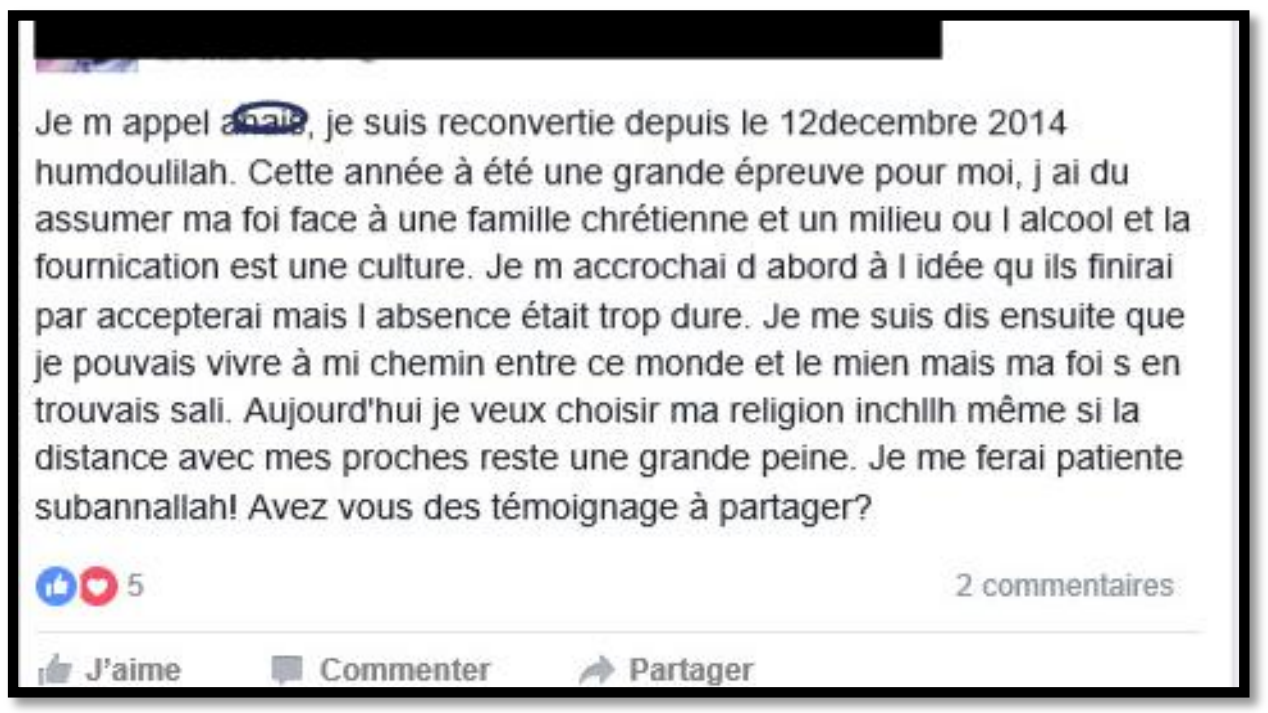

Image 2 : Excerptcaptured on June 10, 2014 (groupe Regroupement des français et européens convertis à l'islam)

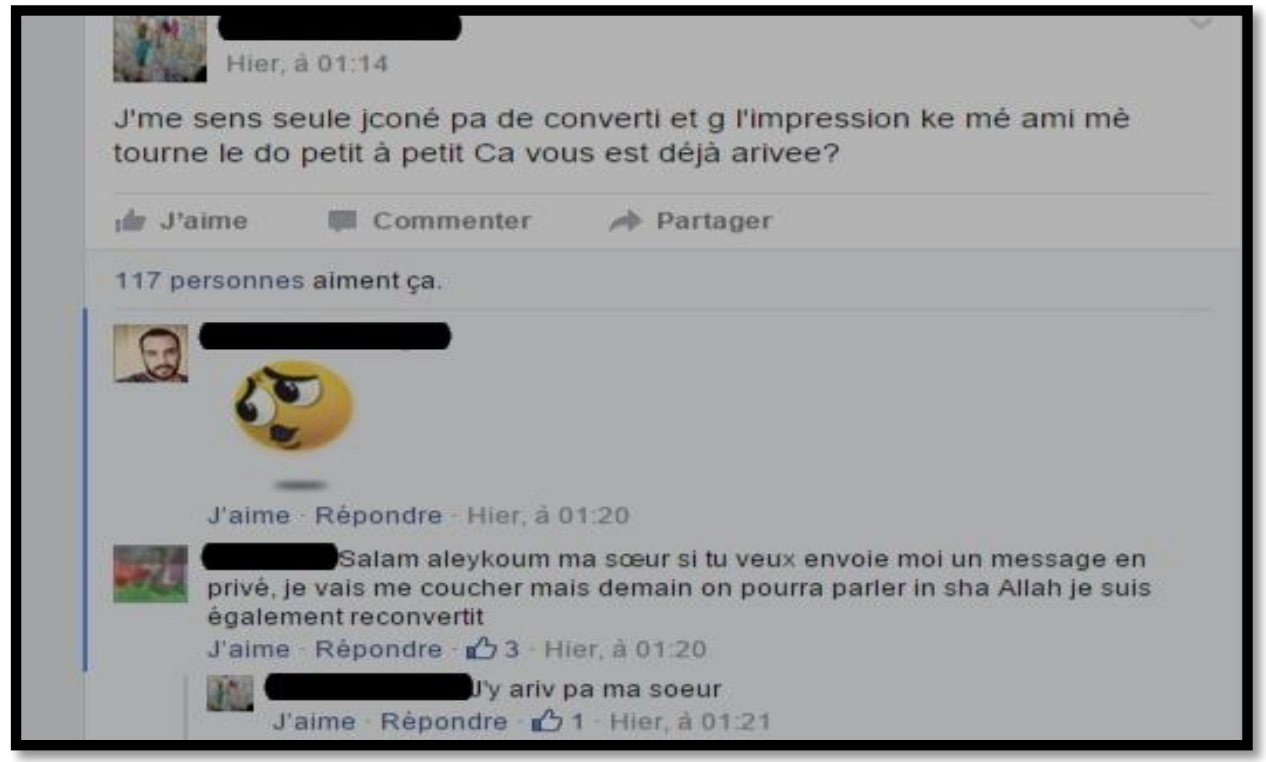

${ }^{7}$ For ethical reasons, the screenshots were anonymized. 
So, many converts feel free to talk about their problems or ask questions that might embarrass them offline. They feel that only other converts with whom they share similar experiences are able to understand and help them. It is precisely for this reason that they adhere to spaces dedicated to converts on Facebook. In this context, converts are at the origin of the production of the different forms of "telepresence" which enable them to maintain social relations at a distance. Geographical distance no longer represents an obstacle to contact. By offering new types of reliance and new ways of acting and being together, Facebook intensifies remote connections between converts and allows for a quasi-permanent regime of "telepresence". The range of functionalities dedicated to communication exchanges such as Facebook messenger or Facebook live video allows for communication comparable to face-to-face exchanges. Fabien Granjon (2011: 101), in an article devoted to social bonding on social networks recalls:

"Nicole Ellison, Charles Steinfeld and Cliff Lampe (2007) thus consider that what distinguishes social networking sites from other communities on the Web is mainly due to the possibility of maintaining a new way of social capital by maintaining contact with Connections (e.g., old friends), despite the vagaries of life and possible biographical breaks".

As a relational catalyst, the social network Facebook contributes to the development of a new culture of social bonding as it allows the reproduction of social networks between remote converts and contributes to a profound transformation of the processes of socialization. Facebook is a space for gathering and exchanging, enabling converts to help each other. Difficulties in regrouping in offline space no longer constitute obstacles to the establishment and maintenance of social relations between converts, thus provoking a community dynamic that can be transferred from offline space to Facebook. Thus, in the online spaces dedicated to converts, one discusses the spirituality and the trajectories of conversion. Online exchange between converts can thus promote affective proximity in the case of sharing similar experiences. It is a source of comfort by sharing experiences with other converts who have had similar experiences and who can provide wise advice. Sharing one's emotions and experiences allows one to build a common history and reduce the feeling of loneliness. From this point of view, Facebook represents a space for socialization that favours the development of solidarity between converts, and contacts established online can be transformed into genuine friendships. The latter are endowed with all the characteristics of the strong links, in the emotional, symbolic and material support offered as well as in the reciprocity, intensity and frequency of the interactional practices.

\section{Conclusion}

As Hervieu-Léger shows (1999), the converted is a key figure allowing us to understand contemporary religious mobility. Through these three examples, it can be noted how conversion to Islam affects the lives of these three women as much in the off-line space as on Facebook. Indeed, the three testimonies clearly show that conversion to Islam is part of a search for piety in order to positively alter its relationship to the world and to God. In this context, Geraldine Mossière (2012: 13) recalled that:

"For women who embrace Islam, for example, the adoption of a healthy lifestyle deemed to purify the body and the mind participates in a self-ethic characteristic of the modern world. Their discourses that borrow the semantics of individual fulfilment and well-being situate their project of self-transformation within the current imperative of personal happiness and achievement".

The converts continue today this search for piety on Facebook, because conversion to Islam cannot be associated only with the profession of the Shabâda, since it permeates the most innocuous acts of their daily lives, inspires their behaviours and underlies all their actions both offline and online.

Thus, thanks to its many features, Facebook promotes the development of new social practices and allows the formation of networks or communities of converts sharing the same interests and the same concerns. Thus, like Amel, Anastasia and Charlene, many French converts to Islam undertake actions, help each other, and build common representations that feed their community and religious imagination. The social network is a new social melting pot where new ways of 'living together' and acting at a distance in real time are crystallizing. In this context, French converts make use of social media by gaining ownership of them, and making them compatible with their daily lives and their interests. However, this research obviously does not allow generalization. Thus, more quantitative studies and longitudinal monitoring would provide objective data on the exact number of converts to Islam using Facebook, and measure the evolution of the social relationships that they are building online. 
It would be necessary to deepen and refine this research, in order to be able to better understand the logics of uses and the reasons that drive many converts to Islam to use social networking sites.

\section{References}

Allievi Stefano., 1998, Les Convertis à l'Islam : les Nouveaux Musulmans d'Europe. Paris:L'Harmattan.

Brun Solène., 2014, Passer la frontière ou brouiller les lignes ? Race, genre et religion : les frontières ethno-raciales au prisme des conversions de femmes à l'Islam en France. MA Thesis in Sociology. Paris: Sciences Po.

Foucault Michel., 2001, L’herméneutique du sujet. Paris, Gallimard.

Granjon Fabien., 2011, « Amitiés 2.0. Le lien social sur les sites de réseaux sociaux », Hermès, La Revue, 1: 99-104.

Hervieu-Léger Danièle., 1999, Le pèlerin et le converti. La religion en mouvement. Paris: Flammarion.

LePape Loïc., 2007, Engagement religieux, engagements politiques : conversions dans une confrérie musulmane. Archives des sciences sociales des religions, 140: 9-27.

Mansson McGinty., A.M., 2006, Becoming Muslim: Western Women’s Conversions to Islam. New York: Palgrave Macmillan.

Mossière Géraldine., 2013, Converties à l’islam. Parcours de femmes au Québec et en France, Montréal: Les Presses de l'Université de Montréal.

Mossière Géraldine., 2012, "Être et "vouloir être »: la conversion comme voie d'herméneutique du soi », ThéoRèmes, 3, [En ligne], 3 | 2012. Available on : https://theoremes.revues.org/383

Popp-BaierUlrike., 2002, Conversion as a Social Construction », in C. HERMANS et al., eds., Social Constructionism and Theology. Leiden/Boston: Brill.

Puzenat Amélie., 2010,Conversions à l'islam et islams de conversion : dynamiques identitaires et familiales. PhD thesis in Sociology. Paris: Université Paris 7.

Rambo Ray Lewis., 1993, Understanding Religious Conversion. New Haven: Hall University Press.

Ricœur Paul., 1990, Soi-même comme un autre. Paris: Seuil.

Riva Virginie., 2015, Converties. Paris: Seuil.

Sakho Jimbira Mohamed., 2015, La protection des données recueillies auprès d'utilisateurs musulmans français sur Facebook: Des enjeux qui dépassent les considérations déontologiques. In : Saleh, Imad, Carayol, Valérie, Leleu-Merviel, Sylvie, Massou, Luc, Roxin, Ioan, Soulages, François, Wrona, Adeline, Zacklad, Manuel et Bouhaï, Nasreddine (éd.), H2PTM'15. Le numérique à l'ère de l'Internet des objets, de l'hypertexte à l'hyperobjet. Londres : Iste Éditions. p. 133144.

Sakho Jimbira Mohamed., 2016, "Islam et réseaux socionumériques : usages et pratiques des utilisateurs musulmans français sur Facebook", REFSICOM [en ligne], Varia. Available on :http://www.refsicom.org/179

SremacSrđan., 2010, Converting into a New Reality: Social Constructionism, Practical Theology and Conversion." Nova Prisutnost,8: 7-27. 